University of Nebraska - Lincoln

DigitalCommons@University of Nebraska - Lincoln

July 2021

\title{
VISUALIZATION OF LIBRARY AND INFORMATION SCIENCE (LIS) JOURNALS IN SCIMAGO: AN ANALYSIS OF FIRST QUARTILE (Q1) JOURNALS
}

Dr. Sudhi S. Vijayan

sudhivijayan@gmail.com

Renjith V. R

University of Kerala, renjithliber@gmail.com

Follow this and additional works at: https://digitalcommons.unl.edu/libphilprac

Part of the Library and Information Science Commons

Vijayan, Dr. Sudhi S. and R, Renjith V., "VISUALIZATION OF LIBRARY AND INFORMATION SCIENCE (LIS) JOURNALS IN SCIMAGO: AN ANALYSIS OF FIRST QUARTILE (Q1) JOURNALS" (2021). Library Philosophy and Practice (e-journal). 5775.

https://digitalcommons.unl.edu/libphilprac/5775 


\title{
VISUALIZATION OF LIBRARY AND INFORMATION SCIENCE (LIS) JOURNALS IN SCIMAGO: AN ANALYSIS OF FIRST QUARTILE (Q1) JOURNALS
}

\author{
Dr. Sudhi S. Vijayan \\ Assistant Professor, \\ Dept. of Library and Information Science \\ University of Kerala, Thiruvananthapuram \\ ORCID: 0000-0002-2228-9031 \\ sudhivijayan@gmail.com \\ V. R. Renjith \\ Reference Assistant \\ Kerala University Campus Library, \\ Kariavattom, Thiruvananthapuram \\ ORCID: 0000-0002-2389-7338 \\ renjithliber@gmail.com
}

\begin{abstract}
The primary goal of the study is to analyze the sixty Q1 journals in LIS as appeared in the SCImago Journal \& Country Ranking (SJR) databases for the year 2020. This article discusses the top Q1 journals in LIS in respect of their scientometric indicators such as SJR, H index, CiteScore and Impact Factor. It also examines the continent, country and publisher wise distribution of Q1 LIS journals in SCImago for the year 2020. The highest SJR value of Q1 journals is 3.507 for the journal 'Information Systems Research' and the journal titled 'IEEE Transactions on Information Theory' has the highest H-index value of 286. The Q1 journal's highest CiteScore and Impact Factor is 14.1 and 8.21 respectively for the journal 'International Journal of Information Management'.
\end{abstract}

Keywords: CiteScore, H-Index, Impact Factor, Library and Information Science Journals, SCImago, Scopus, SJR 


\section{Introduction}

Various kinds of metrics are now available for the quantitative evaluation of scholarly journals. These metrics are used to indicate the level and the influence of scholarly journals. Most of these metrics are obtained by analyzing the citation data of journal articles. The Web of Science (WoS) and Scopus are the most widely used and accepted citation databases regularly employed to rank journals in a discipline in terms of their productivity as well as the total citations received to indicate the journal's impact or influence (Abrizah et al.). In the case of Scopus, there is the SCImago Journal and Country Rank (SJR) (http://www.scimagojr.com), a site that ranks journals with information on various metrics. The SCImago Journal and Country Rank is a publicly available portal which includes scientometric indicators developed from information contained in the Scopus database of Elsevier. Infact, SCImago is a research group from the Consejo Superior de Investigaciones Cientificas (CSIC), University of Granada, Extremadura, Carlos III (Madrid) and Alcala de Henares, dedicated to information analysis, representation and retrieval by means of visualization techniques (SCImago, 2007). It is a significant database that provides valuable information for identifying core journals on a specific subject and is becoming an increasingly helpful tool for ranking scientific journals. The present study is intended to analyze the scientometric indicators of Quartile 1 (Q1) journals in the Library and Information Science (LIS) discipline, based on the data appeared in the SCImago Journal and Country Rank database for the year 2020.

\section{SCImago Quartiles and Scopus CiteScore Percentile}

\subsection{SCImago Quartiles}

Based on the journal's impact index, SJR ranks the journals in each subject category into quartiles ranging from quartile 1 to $4(\mathrm{Q} 1-\mathrm{Q} 4)$. Q1 represents the top 25\% SJR distribution (99th -75 th CiteScore Percentile), Q2 represents middle-high SR distribution (between $50 \%$ to top $25 \%$, i.e. 74th - 50th CiteScore Percentile), Q3 represents middle-low SJR distribution (between $75 \%$ to top 50\%, i.e. 49th -25 th CiteScore Percentile) and Q4 represents the lowest SJR distribution (bottom 25\% SJR distribution, i.e. 24th -0 CiteScore Percentile). 


\subsection{Scopus CiteScore Percentile}

Scopus CiteScore percentile is available in Scopus Source List at https://www.scopus.com/sources.uri. CiteScore Percentile indicates the relative standing of a serial title in its subject field. For example, a serial that has a CiteScore Percentile of 96\% is ranked according to CiteScore as high of higher than $96 \%$ of titles in that category. A title will receive a CiteScore Percentile for each subject area in which it is indexed in Scopus.

Thus the most prestigious journals in a subject field are included in the first quartile or Q1. For the present study, Q1 journals in LIS for the year, 2020 in SCImago are considered.

\section{Review of Literature}

Singh and Pandita (2017) examined the growth of Indian research journals indexed by SCImago Journal and Country Ranking, based on SCOPUS data sources for the period 2005-2014. The distribution of Indian research journals indexed by SCOPUS during the last decade, corresponding annual growth of journals indexed, subject-wise distribution of Indian journals indexed, India's share percentage of journals indexed by SCOPUS both at the continental and the global level are the major key points discussed in the study. The study observed that India is the 6th largest country with maximum (452) journals indexed by the SCImago citation index.

Sudhi Vijayan and Renjith (2017) investigated the journal rankings in the field of LIS based on SCImago Journal and Country Ranking for the year 2015. The paper clarified the significant relationship between different factors of LIS journals and compared the $\mathrm{h}$ index of open access and subscription-based access journals. A regression approach for predicting the $\mathrm{h}$ index based on relevant predictor variables are also discussed in the study.

In another paper, Renjith and Sudhi Vijayan (2018) analyzed the $\mathrm{h}$ index and SJR of 10 LIS journals of the Asiatic region as appeared in the SJR database for the period 2006-2015. Citations, self-citations and citations without self-citations are also analyzed. The study found that the Taiwan LIS journal 'Journal of Information Science and Engineering' has the highest average $\mathrm{h}$ index. The Indian LIS journal 'Annals of Library and Information Science' has the highest SJR value among the LIS journals from the Asiatic region during the period. 
Scopus CiteScore metrics provide inclusive, obvious and contemporary insights into journal impact. Renjith and Shihab (2018) focused on the analysis of CiteScore, Citations and SJR of LIS journals of Asiatic Region based on Scopus CiteScore metrics databases for the period 2011-2015. Correlation among these metrics and difference in metrics among LIS journals are also presented in the study.

Open access journals in LIS enable speedy publication of research findings on emerging trends and trendy topics in the subject field. Renjith (2018), in another paper, investigated the trend of open access LIS journals' metrics, namely SJR, $h$ index and total citation count based on SCImago for the period 2012-2016. It is observed that scientometric indicators of open access journals remain steady during the study period.

Sabha and Bano (2021) used the SJR database to analyze journal ranking and the $\mathrm{H}$ index of the Health Profession journals. The coverage of these journals in Scopus and country ranking in the field of Health Profession are also analyzed in the paper.

\section{Objectives}

1. To identify the growth pattern of Q1 LIS journals in SCImago Journal and Country Rank database from 1999 to 2020.

2. To find out the top Q1 LIS journals in SCImago Journal and Country Rank database for the year 2020 in terms of their scientometric indicators such as SJR, H index, CiteScore and Impact Factor (IF).

3. To identify the continents and countries contributing Q1 LIS journals in SCImago Journal and Country Rank database 2020.

4. To find out the publishers contributing Q1 LIS journals in SCImago Journal and Country Rank database 2020.

5. To identify the Q1 LIS journals having the highest coverage in the Scopus database.

\section{Methodology}

SCImago Journal and Country Rank database 2020 was used as the main source to identify and collect data regarding Q1 LIS journals. We also collected the CiteScore 2019 of Q1 LIS journals 2020 from Scopus Source List on $18^{\text {th }}$ May 2021. The 2019 Journal Impact Factor (JIF) was obtained from Journal Citation Report (JCR) through the Web of Science and the concerned individual journal's website. 


\subsection{Scientometric Indicators}

For each journal, we extracted the following metric indicators.

* SCImago Journal Rank: SCImago Journal Rank measures the weighted citations received by the journal. Citation weighting depends on the subject field and prestige (SJR) of the citing journal.

* CiteScore: CiteScore defines as the average value of citations per item received by the items published in the journal in three previous years.

* H index (Hirsch's $h$ index): The largest number of $(h)$ of publications that have been cited at least " $h$ " times, while all other publications have less than " $h$ " citations.

* Journal Impact Factor (JIF): In a given year, the impact factor of a certain journal is defined as the average value of citations per paper received by the items published in the journal in two previous years.

\section{Analysis and Interpretation}

\subsection{Preliminary Details of the Studies}

A total number of 230 LIS journals are listed in the SJR database for the year 2020. These include 65 Open Access, $148 \mathrm{Web}$ of Science and 8 SciELO journals. These 230 journals are listed under 4 quartiles (Q1-Q4). For the present study, 60 journals coming in the first quartile (Q1) is considered.

Out of $60 \mathrm{Q} 1$ journals, there are 9 open access journals. Open access journals covered by Scopus are indicated as OA if the journal is listed in the Directory of Open Access Journals (DOAJ) and/or the Directory of Open Access Scholarly Resources (ROAD).

There are no SciELO journals in Q1. SciELO (Scientific Electronic Library Online) is a bibliographic database, digital library, and open access journal cooperative electronic publishing model founded in Brazil in 1997. The SciELO network and journal collections now include Argentina, Bolivia, Brazil, Chile, Colombia, Costa Rica, Cuba, Ecuador, Mexico, Paraguay, Peru, Portugal, South Africa, Spain, Uruguay, and Venezuela. SciELO is currently part of Clarivate Analytics.

WoS is a platform created in 1997 consisting of databases designed to support scientific and scholarly research. It contains several databases, which can be searched together. The Web of Science covered journals in Q1 of SCImago is 55. This shows that 
Scopus covers more LIS journals compared to WoS. Moreover, unique LIS journals are indexed by both databases. Since IF is available in JCR of WoS, the IF 2019 value is available only for 52 journals for the present study.

\subsection{Growth of Quartile 1 (Q1) Journals in SCImago}

Figure 1 shows the trend of Q1 journals in SCImago. The number of Q1 journals for the year 2020 is 60 , and at the commencement year 1999, it is 29 only. It is visible that Q1 LIS journals are gradually increasing year by year. Thus an increasing trend can be observed. Similarly, WoS indexed journals in Q1 are also showing a growing trend. In the year 2020, the number of WoS indexed journals in Q1 is 55, and in the year 1999, it is 24. But in the year 2010, the WoS covered journals are less when compared to the previous year. While analyzing the open access journals in Q1 journals, the growth is unstable. From 1999 to 2020, the number of open access journals in Q1 shows an unbalanced trend.

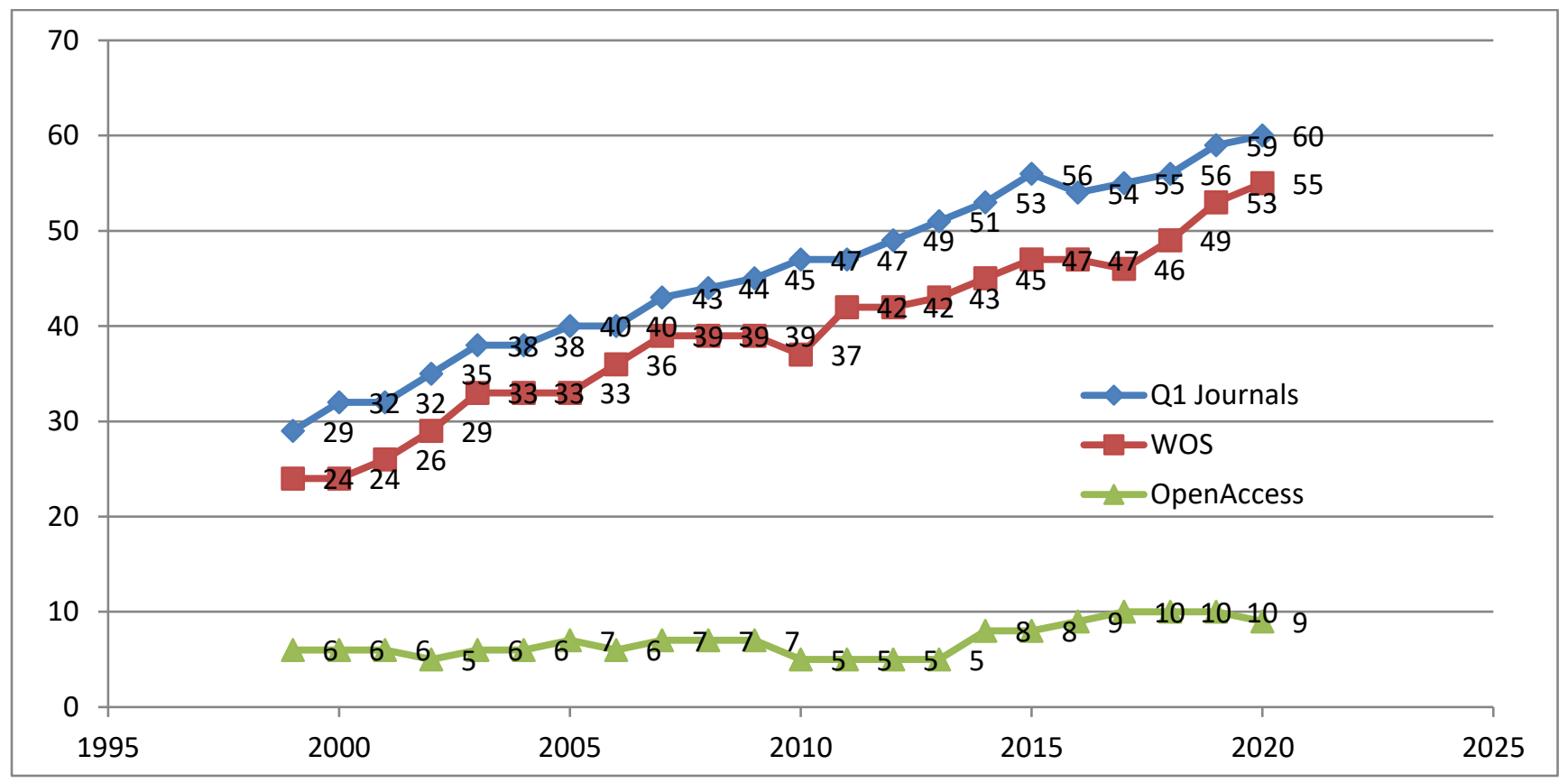

Figure 1: Growth of First Quartile (Q1) LIS Journals in SCImago

\subsection{Scientometric Indicators of Q1 LIS Journals in SCImago 2020}

The scientometric indicators of Q1 journals in LIS are categorized under the following headings. 


\subsubsection{SCImago Journal Ranking Indicator (SJR)}

SCImago Journal Ranking Indicator (SR) measures a journal's impact, influence or prestige. It expresses the average number of weighted citations received in the selected year by the documents published in the journals in the three previous years. Table 1 shows the Top SJR of ten Q1 journals in SCImago 2020.

Table -1

Top SJR of Ten Q1 LIS Journals in SCImago 2020

\begin{tabular}{|c|l|c|}
\hline Sl. No. & \multicolumn{1}{|c|}{ Journals } & $\begin{array}{c}\text { SJR } \\
\mathbf{2 0 2 0}\end{array}$ \\
\hline 1 & Information Systems Research & 3.507 \\
\hline 2 & Information and Organization & 3.298 \\
\hline 3 & Information Communication and Society & 2.806 \\
\hline 4 & International Journal of Information Management & 2.770 \\
\hline 5 & Scientific data & 2.565 \\
\hline 6 & Big Data and Society & 2.244 \\
\hline 7 & Government Information Quarterly & 2.121 \\
\hline 8 & Journal of Information Technology & 1.939 \\
\hline 9 & College and Research Libraries & 1.886 \\
\hline 10 & Journal of Informetrics & 1.605 \\
\hline
\end{tabular}

The SJR value of Q1 LIS journals varied from 0.499 to 3.507. The highest

SJR value among the sixty Q1 journals is 3.507 for the journal 'Information Systems Research', followed by the journal 'Information and Organization' (3.298), and the lowest value is 0.499 for the 'Journal of Information Science'. The mean SJR of Q1 journals is 1.075 .

\subsubsection{H-index (Hirsch's $h$ index)}

The $h$ index was proposed by Hirsch in 2005 as a new metric for evaluating the ability of an individual researcher (Hirsch, 2005). This index is calculated using all citations received by the papers published by a specific researcher. If we arrange these papers in the order of citations received by them and if $h$ papers are cited at least $h$ times, then the maximum number of $h$ is the $h$-index of that researcher. Since it is possible to assign an $h$-index to the group of papers published in a specific journal in a specific year, it can be used as a journal metric. Since the $h$ index is obtained by using the total number of citations of each paper, it increases monotonically with time. Table 2 depicts the top $\mathrm{H}$ index of ten $\mathrm{Q} 1$ journals in SCImago 2020. 
Table -2

Top H index of Ten Q1 LIS Journals in SCImago 2020

\begin{tabular}{|c|l|r|}
\hline Sl. No. & \multicolumn{1}{|c|}{ Journals } & $\begin{array}{c}\text { H index } \\
\mathbf{2 0 2 0}\end{array}$ \\
\hline 1 & IEEE Transactions on Information Theory & 286 \\
\hline 2 & Journal of Chemical Information and Modeling & 160 \\
\hline 3 & Information Systems Research & 159 \\
\hline 4 & Journal of the Association for Information Science and Technology & 145 \\
\hline 5 & Scientometrics & 116 \\
\hline 6 & International Journal of Information Management & 114 \\
\hline 7 & International Journal of Geographical Information Science & 114 \\
\hline 8 & European Journal of Information Systems & 108 \\
\hline 9 & Government Information Quarterly & 103 \\
\hline 10 & Information Processing and Management & 101 \\
\hline
\end{tabular}

The $\mathrm{H}$ index values of Q1 LIS journals range from 6 to 286. The highest $\mathrm{H}$ index value is 286 for the journal 'IEEE Transactions on Information Theory' followed by 'Journal of Chemical Information and Modeling' (160). The lowest Hindex value is 6 for the journal titled 'Journal of Education for Library and Information Science'. The mean H-index of Q1 journals is 58.58.

\subsubsection{CiteScore}

An academic journal's CiteScore reflects the yearly average number of citations to recent articles published. Elsevier introduced this journal evaluation metric in December 2016 as an alternative to the commonly used JCR impact factors (calculated by Clarivate). CiteScore is very similar to the Impact Factor. In CiteScore, the citation window period is three, whereas it is two in the Impact factor. Another difference from the impact factor is that both numerator and denominator include all document types. Table 3 enumerates the top CiteScore of ten Q1 journals in SCImago 2020.

Table -3

Top CiteScore of Ten Q1 LIS Journals in SCImago 2020

\begin{tabular}{|c|l|r|}
\hline Sl. No. & \multicolumn{1}{|c|}{ Journals } & \multicolumn{1}{|c|}{$\begin{array}{c}\text { Citescore } \\
\mathbf{2 0 1 9}\end{array}$} \\
\hline 1 & International Journal of Information Management & 14.1 \\
\hline 2 & Government Information Quarterly & 10.3 \\
\hline 3 & Big Data and Society & 10.2 \\
\hline 4 & Journal of Information Science & 9.8 \\
\hline 5 & Information Processing and Management & 8.6 \\
\hline 6 & Journal of Information Technology & 8.4 \\
\hline 7 & Scientific data & 8.4 \\
\hline 8 & European Journal of Information Systems & 8.3 \\
\hline 9 & Information Communication and Society & 8 \\
\hline 10 & Journal of Library and Information Services in Distance Learning & 7.9 \\
\hline
\end{tabular}


The CiteScore of Q1 LIS journals varied from 14.1 to 0.7. The 'International Journal of Information Management' has the highest CiteScore value of 14.1, followed by 'Government Information Quarterly' (10.3) and the 'Journal of Education for Library and Information Science' has the lowest CiteScore 0.7. The mean CiteScore of Q1 journals is 4.09.

\subsubsection{Impact Factor (IF)}

The idea of impact factor was proposed by Eugene Garfield in 1955 (Garfield, 1955). The Science Citation Index (SCI) was created based on this idea in 1964, and a quantitative evaluation of scholarly journals was launched for the first time. This index is annually announced in the Journal Citation Reports (JCR), which is currently managed by Clarivate Analytics and is widely used by academic communities.

The impact factor (IF) measures how frequently an average article in a journal is cited in a given year. It is used to assess a journal's importance or rank by counting the number of times its articles are cited. One way of determining the impact factor of a journal is by looking at the average number of times, in one year, that articles published in the previous two years have been cited. Table 4 depicts the top IF of ten Q1 LIS journals in SCImago 2020.

Table -4

Top Impact Factor of Ten Q1 LIS Journals in SCImago 2020

\begin{tabular}{|c|l|r|}
\hline Sl. No. & \multicolumn{1}{|c|}{ Journals } & $\begin{array}{c}\text { Impact Factor } \\
\mathbf{2 0 1 9}\end{array}$ \\
\hline 1 & International Journal of Information Management & 8.21 \\
\hline 2 & Scientific data & 5.541 \\
\hline 3 & Journal of Cheminformatics & 5.318 \\
\hline 4 & Government Information Quarterly & 5.098 \\
\hline 5 & Information Processing and Management & 4.787 \\
\hline 6 & Journal of Informetrics & 4.611 \\
\hline 7 & Big Data and Society & 4.577 \\
\hline 8 & Information Communication and Society & 4.559 \\
\hline 9 & Journal of Chemical Information and Modeling & 4.549 \\
\hline 10 & International Journal of Geographical Information Science & 3.733 \\
\hline
\end{tabular}

The IF of Q1 journals range from 0.735 to 8.21. The highest impact factor of

Q1 journal is 8.21 for the journal 'International Journal of Information Management', followed by the journal 'Scientific data' (5.541) and the lowest impact factor value is 0.7 .35 for the journal titled 'Reference Services Review'. The mean 
impact factor of Q1 journals is 2.469. The IF 2019 is available in JCR of WoS only for 52 journals out of 60 Q1 LIS journals in SCImago.

\subsection{Continent-wise Analysis of Q1 LIS Journals in SCImago 2020}

The continents in SCImago have segmented into Africa, Asiatic Region, Eastern Europe, Latin America, Middle East, Northern America, Pacific Region, Western Europe, and Arab countries. There are no SJR journals in the field of library and information science published from Arab countries. Furthermore, continental has classified into BRIICS, EU-28, IBEROAMERICA, LANIC, Nordic countries, and OECD. Because of the repetition of journals in various categories, these have not been considered for the study. Table 5 depicts the continent-wise analysis of Q1 LIS journals in SCImago 2020.

Table -5

Continent-wise Analysis of Q1 LIS Journals in SCImago 2020

\begin{tabular}{|c|l|r|r|r|r|r|}
\hline Sl. No. & Continent & $\begin{array}{c}\text { No. of } \\
\text { Journals }\end{array}$ & $\begin{array}{c}\text { Mean } \\
\text { SJR } \\
\mathbf{2 0 2 0}\end{array}$ & $\begin{array}{c}\text { Mean } \\
\text { H-Index } \\
\mathbf{2 0 2 0}\end{array}$ & $\begin{array}{c}\text { Mean } \\
\text { Citescore } \\
\mathbf{2 0 1 9}\end{array}$ & $\begin{array}{c}\text { Mean } \\
\text { IF } \\
\mathbf{2 0 1 9}\end{array}$ \\
\hline 1 & Asiatic & 1 & 0.514 & 13 & 1 & - \\
\hline 2 & Eastern Europe & 1 & 0.605 & 8 & 1.70 & - \\
\hline 3 & Northern America & 20 & 1.673 & 58.10 & 3.19 & $1.87 *$ \\
\hline 4 & Western Europe & 38 & 1.140 & 61.37 & 8.95 & $2.74 * *$ \\
\hline \multicolumn{7}{|c|}{ Total }
\end{tabular}

The western European continent has the highest number of LIS journals (38) in Q1, followed by Northern America (20). The remaining two journals are from the Asian and the Eastern European continent, respectively (Table 5).

Regarding the mean SJR of Q1 journals, Northern American LIS journals have the highest average SJR of 1.673, followed by Western European journals (1.140). The average $\mathrm{H}$ index value of Western European journals is high (61.37) compared to that of Northern American journals (58.10). Similarly, the mean CiteScore of Western European journals (8.95) are higher than North American journals (3.19). But in the case of the average Impact factor, Western European LIS journals have the highest average IF value of 2.74, followed by Eastern European journal (1.87) (Table 5). 


\subsection{Country -wise Analysis of Q1 LIS Journals in SCImago 2020}

Scholarly journals in the subject field of LIS are published from different countries across the world. The Q1 LIS journals included in the SCImago 2020 are published from seven countries. UK and USA are the most contributing countries with 34 and 19 LIS journals, respectively. The Netherlands contribute 3 journals, and the remaining 4 countries contribute 1 journal each in Q1 of SCImago 2020 (Table 6).

Table -6

Country-wise Analysis of Q1 LIS Journals

\begin{tabular}{|c|c|c|c|c|c|c|}
\hline Sl. No. & Country & $\begin{array}{c}\text { No. of } \\
\text { Journals }\end{array}$ & $\begin{array}{c}\text { Mean } \\
\text { SJR } \\
2020 \\
\end{array}$ & $\begin{array}{c}\text { Mean } \\
\text { H-Index } \\
2020 \\
\end{array}$ & $\begin{array}{c}\text { Mean } \\
\text { Citescore } \\
2019 \\
\end{array}$ & $\begin{array}{c}\text { Mean } \\
\text { IF } \\
2019 \\
\end{array}$ \\
\hline 1 & Canada & 1 & 0.716 & 6 & 0.7 & - \\
\hline 2 & India & 1 & 0.514 & 13 & 1 & - \\
\hline 3 & Netherlands & 3 & 1.168 & 81.33 & 4.1 & 3.18 \\
\hline 4 & Poland & 1 & 0.605 & 8 & 1.7 & - \\
\hline 5 & Spain & 1 & 0.698 & 28 & 2.1 & 1.58 \\
\hline 6 & UK & 34 & 1.151 & 60.59 & 4.8 & $2.73 *$ \\
\hline 7 & USA & 19 & 0.438 & 60.84 & 3.3 & $1.87 * *$ \\
\hline \multicolumn{2}{|c|}{ Total } & 60 & & & & \\
\hline
\end{tabular}

*Average IF of 32 journals ** Average IF of 16 journals

The mean SJR of Netherlands LIS journals (1.168) are moderately higher than that of other countries LIS journals and also mean $\mathrm{H}$ index value of Netherlands journals (81.33) are far higher than other countries mean $\mathrm{H}$ index. UK LIS journals have the highest average CiteScore value of 4.8 followed by Netherlands LIS journals (4.1). The highest mean IF value is occupied by Netherlands journals (3.18) followed by UK LIS journals (2.73) (Table 6).

\subsection{Publisher-wise Analysis of Q1 LIS Journals in SCImago 2020}

Academic LIS scholarly journals are published by renowned publishers from different parts of the world. Table 7 reveals that the leading publishers are publishing Q1 LIS journals and their corresponding scientometric indicators. 
Table -7

Publisher-wise Analysis of Q1 LIS Journals

\begin{tabular}{|c|c|c|c|c|c|c|}
\hline $\begin{array}{l}\text { Sl. } \\
\text { No. }\end{array}$ & Publisher & $\begin{array}{c}\text { No. of } \\
\text { Journals }\end{array}$ & $\begin{array}{c}\text { Mean } \\
\text { SJR } \\
2020\end{array}$ & $\begin{array}{c}\text { Mean } \\
\text { H- } \\
\text { Index } \\
2020\end{array}$ & $\begin{array}{c}\text { Mean } \\
\text { Citescore } \\
2019\end{array}$ & $\begin{array}{c}\text { Mean } \\
\text { IF } \\
2019\end{array}$ \\
\hline 1 & Taylor \& Francis & 15 & 0.86 & 44 & 3.34 & $1.94 *$ \\
\hline 2 & Emerald Insight & 9 & 0.63 & 48 & 2.60 & 1.52 \\
\hline 3 & Elsevier & 7 & 1.85 & 81 & 6.80 & $3.03^{* *}$ \\
\hline 4 & Springer Science + Business Media & 4 & 0.87 & 62 & 3.98 & $2.03 * * *$ \\
\hline 5 & SAGE Journals & 4 & 1.19 & 51 & 7.05 & 2.79 \\
\hline 6 & Oxford Academic & 2 & 0.86 & 33 & 3.95 & $2.57 * * * *$ \\
\hline 7 & Johns Hopkins University Press & 2 & 1.60 & 86 & 3.40 & 1.62 \\
\hline 8 & American Library Association & 1 & 0.50 & 34 & 1.40 & 0.81 \\
\hline 9 & DRDO & 1 & 0.51 & 13 & 1.00 & N/A \\
\hline 10 & National Science Library & 1 & 0.61 & 8 & 1.70 & N/A \\
\hline 11 & EPI & 1 & 0.70 & 28 & 2.10 & 1.58 \\
\hline 12 & $\begin{array}{l}\text { Association for Library and } \\
\text { Information Science Education }\end{array}$ & 1 & 0.72 & 6 & 0.70 & N/A \\
\hline 13 & Wiley Online Library & 1 & 0.78 & 38 & 2.60 & 1.36 \\
\hline 14 & Portland State University & 1 & 0.86 & 16 & 2.60 & N/A \\
\hline 15 & Wiley-Blackwell & 1 & 0.90 & 145 & 2.80 & 2.41 \\
\hline 16 & University of Chicago Press & 1 & 0.97 & 38 & 2.90 & 1.47 \\
\hline 17 & University of Pittsburgh & 1 & 1.10 & 58 & 3.60 & 2.04 \\
\hline 18 & IEEE Information Theory Society & 1 & 1.22 & 286 & 6.50 & 3.04 \\
\hline 19 & American Chemical Society & 1 & 1.24 & 160 & 6.30 & 4.55 \\
\hline 20 & BioMed Central & 1 & 1.35 & 55 & 7.80 & 5.32 \\
\hline 21 & $\begin{array}{l}\text { Association of College and } \\
\text { Research Libraries }\end{array}$ & 1 & 1.89 & 52 & 3.50 & 2.05 \\
\hline 22 & Palgrave Macmillan & 1 & 1.94 & 79 & 8.40 & 3.63 \\
\hline 23 & Nature Research & 1 & 2.57 & 64 & 8.40 & 5.54 \\
\hline 24 & $\begin{array}{l}\text { Institute for Operations Research } \\
\text { and the Management Sciences }\end{array}$ & 1 & 3.51 & 159 & 6.60 & 3.59 \\
\hline & $\begin{array}{rc}\text { Total } \\
\end{array}$ & 60 & 0.49 & 27.41 & 1.67 & 1.02 \\
\hline
\end{tabular}

*IF for 14 journals $* *$ IF for 6 journals $* * *$ IF for 3 journals $* * * *$ IF for 1 journal

The 2020 SJR database contained 60 Q1 LIS journals. Of them, Taylor \& Francis publish 15, Emerald Insight publishes 9, Elsevier publishes 7 and 4 journals each by Springer Science + Business Media and SAGE Journals. Oxford Academic and Johns Hopkins University Press publish 2 journals each. The remaining 17 publishers publish one journal each. 


\subsection{Coverage of Q1 LIS Journals in Scopus}

Table 8 showcases the 12 Q1 LIS journals having the highest coverage in Scopus. The highest coverage in years (76 years) is attained for the journal 'Journal of Documentation' published by Emerald Insight which covers the period from 19452020, while 'Journal of Data and Information Science' and 'Journal of Education for Library and Information Science' journals accomplished minimum coverage of only four years. The mean coverage period is 28.67 .

Table -8

Highest Coverage of Q1 LIS Journals in Scopus

\begin{tabular}{|c|c|c|c|c|c|c|}
\hline $\begin{array}{l}\text { SI. } \\
\text { No. }\end{array}$ & Journal & $\begin{array}{c}\text { Years } \\
\text { covered }\end{array}$ & $\begin{array}{l}\text { Coverage } \\
\text { Periods }\end{array}$ & Publisher & Country & Continent \\
\hline 1 & $\begin{array}{c}\text { Journal of } \\
\text { Documentation }\end{array}$ & 76 & $1945-2020$ & Emerald Insight & UK & $\begin{array}{l}\text { Western } \\
\text { Europe }\end{array}$ \\
\hline 2 & $\begin{array}{l}\text { IEEE Transactions } \\
\text { on Information } \\
\text { Theory }\end{array}$ & 58 & $1963-2020$ & $\begin{array}{l}\text { IEEE Information } \\
\text { Theory Society }\end{array}$ & USA & $\begin{array}{l}\text { Northern } \\
\text { America }\end{array}$ \\
\hline 3 & $\begin{array}{c}\text { Journal of } \\
\text { Librarianship and } \\
\text { Information } \\
\text { Science } \\
\end{array}$ & 52 & $1969-2020$ & SAGE Journals & UK & $\begin{array}{l}\text { Western } \\
\text { Europe }\end{array}$ \\
\hline 4 & $\begin{array}{c}\text { Reference Services } \\
\text { Review }\end{array}$ & 48 & $1973-2020$ & Emerald Insight & UK & $\begin{array}{l}\text { Western } \\
\text { Europe }\end{array}$ \\
\hline 5 & $\begin{array}{c}\text { Information } \\
\text { Processing and } \\
\text { Management }\end{array}$ & 46 & $1975-2020$ & Elsevier & UK & $\begin{array}{l}\text { Western } \\
\text { Europe }\end{array}$ \\
\hline 6 & Scientometrics & 43 & $1978-2020$ & $\begin{array}{c}\text { Springer Science } \\
+ \text { Business Media }\end{array}$ & Netherlands & $\begin{array}{l}\text { Western } \\
\text { Europe }\end{array}$ \\
\hline 7 & $\begin{array}{l}\text { Collection } \\
\text { Management }\end{array}$ & 42 & $\begin{array}{c}1976, \\
1978- \\
1979 \\
1981- \\
1999 \\
2001-2020\end{array}$ & Taylor \& Francis & USA & $\begin{array}{l}\text { Northern } \\
\text { America }\end{array}$ \\
\hline 8 & $\begin{array}{c}\text { Library } \\
\text { Management }\end{array}$ & 42 & $1979-2020$ & Emerald Insight & UK & $\begin{array}{l}\text { Western } \\
\text { Europe }\end{array}$ \\
\hline 9 & $\begin{array}{c}\text { Journal of } \\
\text { Information } \\
\text { Science } \\
\end{array}$ & 42 & $1979-2020$ & SAGE Journals & UK & $\begin{array}{l}\text { Western } \\
\text { Europe }\end{array}$ \\
\hline 10 & $\begin{array}{l}\text { Online Information } \\
\text { Review }\end{array}$ & 41 & $1980-2020$ & Emerald Insight & UK & $\begin{array}{l}\text { Western } \\
\text { Europe }\end{array}$ \\
\hline 11 & Library Trends & 41 & $1980-2020$ & $\begin{array}{c}\text { Johns Hopkins } \\
\text { University Press }\end{array}$ & USA & $\begin{array}{l}\text { Northern } \\
\text { America }\end{array}$ \\
\hline 12 & $\begin{array}{l}\text { Journal of Library } \\
\text { Administration }\end{array}$ & 41 & $1980-2020$ & Taylor \& Francis & USA & $\begin{array}{l}\text { Northern } \\
\text { America }\end{array}$ \\
\hline
\end{tabular}


Emerald Insight publishes the highest Scopus covered (76 years) Q1 LIS journal 'Journal of Documentation' from the UK in the Western European Continent. The lowest Scopus covered (4 years) Q1 journals are 'Journal of Data and Information Science' and 'Journal of Education for Library and Information Science'. These journals are published by National Science Library and Association for Library and Information Science Education, respectively. The former journal is published from Poland in the Eastern European continent, and the latter is from Canada in Northern America.

\section{Conclusion}

The SCImago Journal and Country Rank provide free online access and visualize various scientometric aspects of the multidisciplinary scientific journals and other bibliometric resources. The scientometric indicators visualized in SJR can be used to assess and analyze different scientific domains. The SCImago Journal Rank indicator excludes self-citations and considers the quality rather than absolute numbers of citations of a journal by other journals. They provide new opportunities to analyze and understand their effects on the ranking of journals. Journals and country ranking can be compared and analyzed separately in this database. As an increasingly helpful tool for ranking scientific journals, it is an important database providing valuable information for the identification of core journals on a particular subject.

\section{References}

Abrizah, A., Zainab, A., Kiran, K. \& Raj, R. (2013). LIS journals scientific impact and subject categorization: A comparison between Web of Science and Scopus. Scientometrics, 94(2), 721-40.

Ali, Sabha and Bano, Shohar, (2021). Visualization of journal ranking using a SCImago: an analytical tool. Library Philosophy and Practice (e-journal). 5353. https://digitalcommons.unl.edu/libphilprac/5353

Bornmann, Lutz and Marx, Werner. (2011). The $\mathrm{h}$ index as a research performance indicator. European Science Editing, 37(3), 77. http://www.lutzbornmann.de/icons/ viewpoints.pdf.

Garfield, E. (1955), Citation indexes for science: a new dimension in documentation through association of ideas. Science, 122, 108-11. http://doi.org/10.1126/science.122.3159.108 
Hirsch, J. E. (2005). An index to quantify an individual's scientific research output. PNAS, 102, 16569-72. http://doi.org/10.1073/pnas.0507655102

Publications Impact Indexes (2021, May 18). https://www.mondragon.edu/ en/web/biblioteka/ publications-impact-indexes\#6

Renjith, V. R. \& Ilias, S. (2018). Scopus cite score metrics of LIS journals of Asian countries during 2011-2015: A statistical approach. International Journal of Information Dissemination and Technology, 8(2), 121-124.

Renjith, V. R. \& Sudhi Vijayan, S. (2018). Statistical analysis of Library and Information Science (LIS) journals of Asiatic region during 2006-2015: A study based on SCImago Journal and Country Ranking. International Journal of Information Studies and Libraries, 3(2), 20-26.

Renjith, V. R. (2018). Scientometric indicators of open access journals in Library and Information Science: A trend analysis for 2012-2016. ILIS journal of Librarianship and Informatics, 1(1). 42-48.

SCImago. (2021, May 18). SJR-SCImago Journal and Country Rank. http://www.scimagojr.com Scopus Citescore (2021, May 18). Scopus. https://www.scopus.com/sources.uri.

Singh,S \& Pandita, R. Indexing of Indian Journals in SCImago Citation Database: A Decadal Study (2005-2014). DESIDOC Journal of Library \& Information Technology, 37(1), 51-57 DOI: 10.14429/djlit.37.1.10343

Sudhi, S. V., \& Renjith, V.R. (2017). Statistical Analysis of SCImago Journal Ranking in the Field of Library and Information Science. Sadakath: A Research Bulletin (NO. 64130). https://papers.ssrn.com/sol3/papers.cfm?abstract_id=3560918 